\title{
INTERRELATION BETWEEN SUPPLY CHAIN MANAGEMENT AND LOGISTICS: A CASE STUDY IN THE BRAZILIAN PLANT OF A MULTINATIONAL AUTOMOTIVE COMPANY
}

\section{INTER-RELAÇÕES ENTRE GESTÃO DA CADEIA DE SUPRIMENTOS E LOGÍSTICA: UM ESTUDO DE CASO NA PLANTA BRASILEIRA DE UMA EMPRESA AUTOMOTIVA MULTINACIONAL}

\author{
Jonas Lucio Maia ${ }^{1}$; Aline Lamon Cerra ${ }^{2}$ \\ ${ }^{1}$ Universidade Federal de São Carlos - UFSCar - São Carlos - Brasil \\ jonasmaia@dep.ufscar.br \\ ${ }^{2}$ Universidade Federal de São Carlos - UFSCar - São Carlos - Brasil \\ alinelc@terra.com.br
}

\begin{abstract}
Brazilian automotive industry has suffered structural changes, like lean manufacturing adoption, the set up of new productive chains, changes in product design, etc. In such context, this paper aims at introducing a case study carried out in an engine assembler located in Brazil, and analyzing aspects concerning Logistics and Supply Chain Management taking place in this company, in order to describe how these concepts are actually implemented in the company, and illustrate the relationship and mutual influence that exists between these areas. The case studied makes its contribution in the sense of highlighting the strong inter-relationship taking place between aspects that compose Supply Chain Management, here included logistics (location, inventory, and transportation, among others) and the characteristics of structure, relationship and alignment pertaining to Supply Chain Management. In the case studied, given the strong mutual influence among its factors, as well as the dependence on previous strategic choices, decisions made in the Supply Chain Management sphere, and thus in the logistics one, are assigned even more complexity and strategic relevance.
\end{abstract}

Keywords: Supply Chain Management; Strategy; Logistics; Automotive Industry

\section{Introduction}

According to Salerno et al. (2003), the worldwide automotive industry has undergone a process of important changes, which go beyond the adoption of lean practices and philosophy. In a nutshell, these changes have taken place into three major areas: internal production restructuring, by adopting lean practices; establishment of new supplying relationships, as a result of the new commercial blocks and new organizational configurations (modular, industrial condominium, etc.); 
and changes in product design activities, given the new $\mathrm{CAD} / \mathrm{CAM} / \mathrm{CAE}$ technologies and the introduction of the "world car" concept.

In Brazil, with the economy opening, the automotive industry has experienced remarkable restructuring since 1995, when several car assemblers set up new facilities in regions without previous tradition in the automotive scenario. During this period of time, the automakers underwent a process of growth and investment, while the auto suppliers experienced a period of consolidation and denationalization (POSTHUMA, 1997).

In this sense, Brazilian automakers have undertaken distinct competitive strategies during this period and have established new sorts of relationships with auto-part suppliers, inserted into new company networks and having, as a consequence, to adopt logistical systems and supply chain managerial practices that were suitable to such new contexts.

One should also note that many definitions of scope for Logistics and Supply Chain activities may be found in the literature, considering the possibilities that (1) they are synonyms, (2) that the former comprises the latter or (3) vice-versa.

This work considers Logistics to be a constituting part of Supply Chain Management (SCM), being responsible for the material and information flows between the companies belonging to the chain, whereas SCM also comprises issues like Sourcing and Procurement, Outsourcing, Partnership relations, Product co-design, etc.

However, as Maia (2006) argues, there are important conditionants between Logistics and Supply Chain Management and, in practice, the relationship between both areas is made rather complex given the mutual impacts that decisions made in one area may have on the other.

Thus, considering such theoretical context, and taking into consideration the fact that Brazilian automotive industry has experienced important changes in its supply chains, the work here presented aims at contributing to such debate by shedding light on the inter-relationship and mutual influence between Logistics and Supply Chain Management in a case study carried out in an automotive engine manufacturer located in Brazil.

This paper can be outlined as follows: the first sections summarize a literature review about Logistics and Supply Chain Management concepts; the next section presents the research method used in this work and introduces the case study. The last section presents final remarks, derived from the analysis of the concerning topics in the company studied.

\section{Literature Review}

Several definitions for "Logistics" and "Supply Chain Management" exist in the literature. Some researchers consider both terms as synonyms, others regard Supply Chain as a broader 
concept that encompasses Logistics, while others understand Logistics as comprising SCM.

In the context of this paper, SCM will be considered to encompass Logistics activities, and this understanding will guide the literature review: first, Supply Chain Management will be presented, with its definitions, assumptions, etc. Then, Logistics activities will be summarized and, concluding, some remarks on the SCM-logistics relationship will be sketched.

\subsection{Supply Chain Management}

The factors that make possible the success of a given supply chain are those in which each member, besides having individual excellence, accomplishes partnerships by means of which, it shares values, and relationships that fulfill the goals of all the members. In other words, a wellsucceeded supply chain is conceived in a context of flexibility and shared value creation, and not only of market exchanges (SOUZA et al., 2005).

Thus, it's acknowledged that there are important benefits to be derived from strategically managing the whole supply chain towards end-users satisfaction (SLACK et al., 1997; LUMMUS et al., 1998). In this new context, Supply Chain Management originated.

A supply chain comprises all the stages (clients, retailers, distributors, manufacturers and suppliers) involved, directly or indirectly, in the fulfillment of a client order (CHOPRA; MEIDL, 2003). It can be seen, according to Lumus et al. (1998), as a network of entities that comprises the whole flow of materials and information.

The main goal of SCM is to make the business process more effective and efficient, reducing costs and inventory levels, improving quality and creating sustainable competitive advantage to the whole supply chain (ALVES FILHO et al., 2001).

According to Croom et al. (2002), the SCM concept isn't still completely understood, once that there is not a single definition for it. The authors point out as a reason the multidisciplinary character of it, once that the concept concerns many research areas: transaction cost economy, network theory, logistics and transportation, etc.

The Supply Chain Management definition that will be here adopted is "the integration of the main processes that manage materials and information bi-directional flows, within the ambit of the enterprise and between the companies that take part into the supply chain, until reaching the endconsumers, and having as main goal to aggregate value to the stakeholders and to the clients along these processes" (PEDROSO, 2002, p.21). 
Figure 1: Main Supply Chain Management assumptions

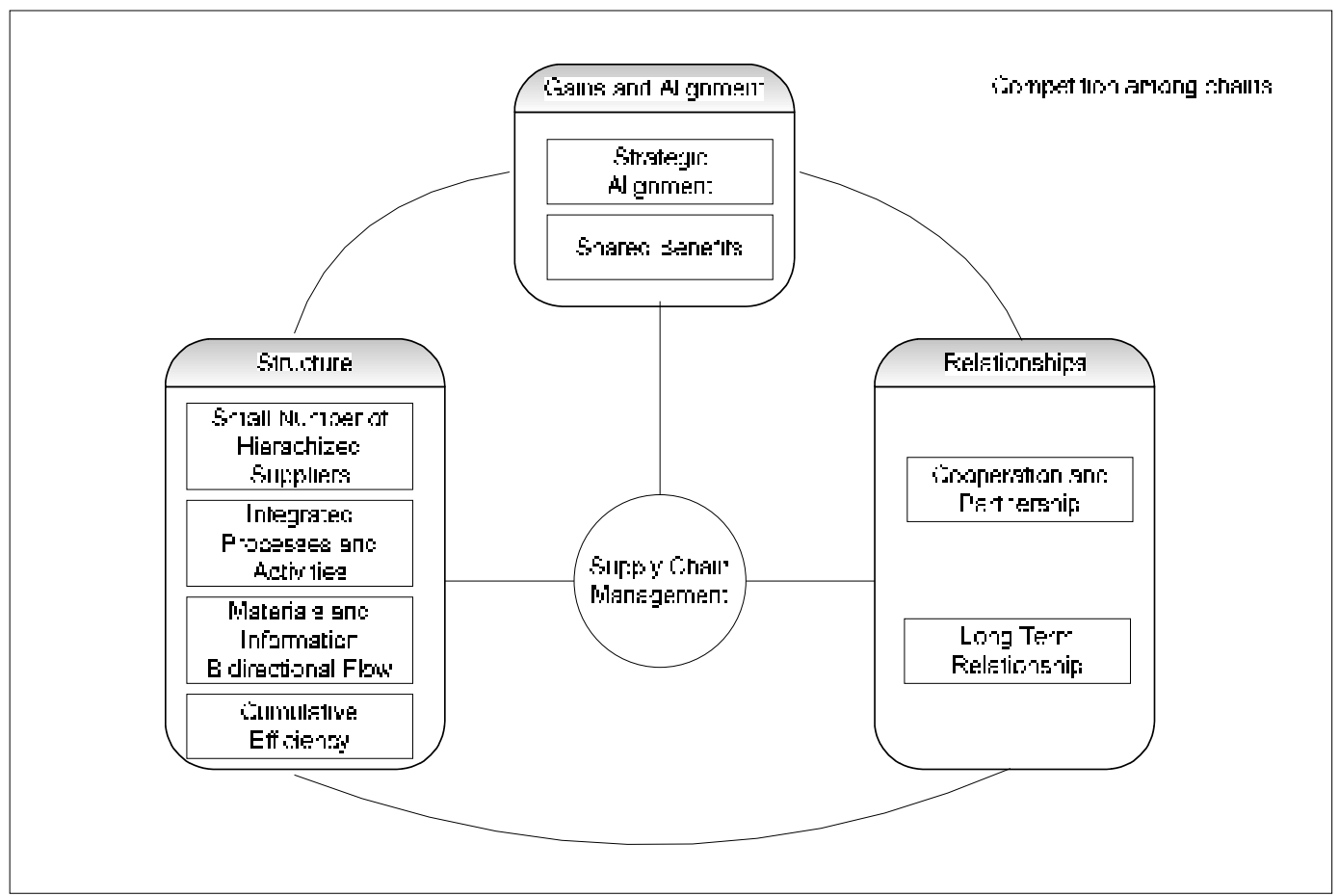

Source: Alves Filho et al. (2004) .

Figure 1, proposed by Alves Filho et al. (2004), summarizes the Supply Chain Management main assumptions, grouped into four sets that concern : (1) the competitive environment, (2) strategic alignment and gain sharing, (3) chain structure and (4) the relationships between the companies in the chain.

The first subset of assumptions concerns the manner in which companies and researchers perceive the competitive environment. According to Christopher (1998), such environment has undergone a restructuring process, so that competition now takes place among entire chains, and not among isolated companies anymore.

The second group of assumptions originates from the first one. If competition now takes place among supply chains, companies must have their strategies aligned, so that individual actions generate gains for the whole chain. The counterpart of strategic alignment would be an even gain sharing among the companies, according to the efforts and investment made by each one.

The third subset encompasses aspects concerning structural aspects, i.e. the roles that companies and productive units play inside the chains. It includes the existence of a small number of hierarchized suppliers, the integration of process and activities throughout the chain, the occurrence of an efficient material and information bidirectional flow, and the efforts that each company undertakes in order to reduce its own complexity (thus reducing the complexity of the whole chain). 
The fourth group concerns the relationships between the companies inside the supply chain. It deals with establishing cooperative and long term relations, as well as partnerships between companies.

After having presented the SCM aspects, the next subsection is concerned about presenting Logistics, which is directly connected to the issue of material and information bidirectional flow, pertaining to the third subset of SCM assumptions.

\subsection{Logistics}

In the context of this paper, Logistics will be defined as "the part of Supply Chain Management that plans, implements and controls the effective and efficient flow and storage (in both directions) of goods, services and related information, from the origin to the consumption point, in order to fulfill client's requirements" (COUNCIL OF SUPPLY CHAIN MANAGEMENT PROFESSIONALS, 2005). Thus, Logistics will be seen as a set of activities inserted into the wider context of a supply chain.

In order to strategically manage logistics, Christopher (1998) proposes a sequence of steps, which comprises (1) Identify customers' service needs, (2) Define customer service objectives and (3) Design the logistics system itself.

The first step encompasses developing deep knowledge of the customer market, identifying the key components of customer service, establishing the relative importance of them, and identifying customer service segments.

Step (2) tries to translate this information into levels of performance in standard measures. According to Bowersox and Closs (1997), logistical service level includes three fundamental dimensions: availability, operational performance and dependability. Availability means holding inventories in order to consistently fulfill customer demands, operational performance deals with the time elapsed between order receipt and fulfillment (specifying the desired performance in terms of speed, consistency, flexibility and failures/recovering), while dependability encompasses logistics quality attributes, being meeting the planned levels of availability and operational performance a key-aspect.

The third step takes the results from steps (1) and (2) as guidelines to actions in the decision areas that will be explained below.

Those customer service parameters will be translated into a series of actions that will be taken into corporative key areas, so that this pattern of actions will make feasible the achievement of the logistical service goals. Ballou (1999) has proposed logistics network design, inventory and transportation management as those key decision areas, and Bowersox and Closs (1996) has added 
packaging, warehousing and information management in these areas.

The network design area encompasses fixing the number, location, and size of the facilities and assigning market demand to them, as a manner to determine the paths through which products are directed to the marketplace.

Inventory decisions refer to the manner in which inventories are managed. Such decisions may concern allocating (pushing) inventories to stocking points or pulling them into these points through replenishment rules, locating selectively various items in plant, regional or field warehouses and managing inventory levels by various control methods, among others.

Transport decisions can involve mode selection, shipment size, routing and scheduling. These decisions are influenced by the proximity of warehouses to customer and plants which, in turn, influence warehouse location. Inventory levels also respond to transport decisions through shipment size.

Packaging decisions also have a significant impact on the cost and productivity of the logistical system. The purchase of packaging materials, the institution of automated and manual packaging operations, and the subsequent need for material disposal have a direct influence on the other logistical areas.

Information management concerns the communication and processing technologies used, order processing systems, as well as the forecasts, which allow logistics managers to proactively allocate resources rather than reacting to needs with expensive changes in capacity and inventory.

\subsection{Relations between SCM and Logistics}

Mainly during the 80 's, global competition has impelled companies to provide even lower costs, higher quality, more endurable products, and higher product flexibility. In this context, several programs, techiniques and technologies directly or indirectly related to Logistics, like the JIT (Just In Time), ECR (Efficient Customer Response), EDI (Electronic Data Interchange), among others, allowed for inventory reductions and better coordination of the material flow along productive chains (MUSETTI, 2000).

Expanding such concept, companies started to think "outside the boundaries", becoming aware of the importance and potential benefits of cooperative relationships with suppliers and clients. Thus, strategic partnerships started to emerge, contributing to the origin of Supply Chain Management.

This historical evolution can be considered the first relationship between SCM and Logistics. According to Alves Filho et al. (2004), SCM originated mainly from the developments in Logistics. 
A second relation between SCM and Logistics can be discussed by analyzing the activities encompassed by each concept.

One of the main assumptions by SCM is that a efficient bidirectional flow of products (goods and services) and information must take place between all the companies belonging to the chains (LAMBERT et al., 1996). On the other hand, as already mentioned in section 2.2, Logistics implements and controls the effective and efficient flow and storage (in both directions) of goods, services and related information,

In this sense, a second relation can be identified between SCM and Logistics activities: the latter is directly responsible for part of the former. Also, Pires; Ayres (2000) argue that companies which implement valuable SCM partnerships believe that such relations encompass more than Logistics, i.e., SCM partnerships probably comprises more processes and functions than Logistics management do.

The last point of confluence between SCM and Logistics concern the conditionants between both concepts.

According to Maia (2006), Supply Chain Management is involved with defining supply chain structure, which, in turn, creates the framework inside which all Logistical operations take place. For example, supplier location (SCM issue) have a direct impact on the in-house inventory levels a client must hold, once that hypothetically, distant suppliers imply high transportation leadtimes, which imply high inventory levels.

The inverse influence (Logistics affecting SCM) can also be conceived of, once that, for example, the usage of transportation methods with shorter lead times (Logistics issue) may allow a company to outsource its products to more distant suppliers (SCM issue), without jeopardizing inventory costs.

\section{Research Method}

The research strategy here adopted was the case study, once that in accordance to Yin (1994, p. 23), this work intended to "investigate an actual phenomenon inside its reality context, when the boundaries between the phenomenon and the context are not clearly defined and in which multiple evidence sources are used".

As a first step in the research conduction, a literature review on Logistics and Supply Chain was carried out, as a manner to support the following stages that would be developed. Besides the case study method, this work relied on a documental research, using information about recent empirical studies on the automotive industry found in (ALVES FILHO et al., 2001).

The field research, having been accomplished by means of case studies, can be characterized 
as qualitative and exploratory. According to Lazzarini (1997), the so-called qualitative methods have a major focus on understanding the facts, instead of measuring them. The data collection technique here used was the interview, which according to Selltiz et al., apud Gil (1999, p.117), "is quite suitable for gathering information about what people know, believe, hope, fell or wish, intend to do, do or did, as well as about their explanations or reasons about the preceding things."

Due to the fact that some issues here studied are firm-specific, the interviews used a semistructured approach, in order to have the flexibility needed to analyze such issues.

Altough it is not intended here to describe the interview questionnaire in great detail, it's worth mentioning the use of a questionnaire based on a previous literature review, which mainly comprised three sections of questions: the first concerning the structure of the supply chains, the clients served, active suppliers, products, etc.; the second concerning the relations taking place inside those chains, like product co-desing, outsourcing, bargaining power, etc.; and the last one about logistics operational activities, such as network design, inventory, transportation and information management.

Given the objectives of this research, the interviewees were preferentially those working in the logistics, purchasing and product engineering areas, most of them helding senior management positions.

\section{Case Study}

\subsection{Company Overview}

The company here studied assembles car engines, especially those of low and medium displacement, having a close relationship to its headquarters in Europe.

In the Brazilian branch, the engine production is divided into three areas: (1) Blocks, crankshafts and cylinder head machining, (2) final assembly and (3) tool maintenance and switching. There is an Integrated Quality System, through which the engine assembly is monitored, from machining the first part until installing the engine into the vehicle.

Concerning the development of new engines, the activities are restricted to incremental improvements, e. g. the development of alternative kinds of fuel, improvement of efficiency and power in low-displacement engines, conduction of research on emission levels, etc.

Production mix and volume has increased but, in certain cases, the production of a new engine implies the exclusion of a previous model, what means that a product substitution actually takes place.

The assembler has installed capacity to produce 1900 engines, on three shifts, and 1700 transmissions, also on three shifts. 


\subsection{Supply Chain Management}

The company's clients are the car assemblers, with whom the studied enterprise has permanent contact.

The outsourcing level can be considered high in this company, once that the suppliers are responsible for most of the engine parts. From the outsourced parts, about $20 \%$ of them are imported. It's important to mention that the company, however, has not outsourced the machining of the engine block, crankshaft and cylinder head, once that it considers that those parts define essential characteristics of a engine, like performance and fuel consumption.

The purchasing department, responsible for managing suppliers, makes the connection between suppliers and the product development group, besides monitoring the quality of those enterprises.

Concerning supplier quality management, the assembler demands that all of its suppliers be at least certified in ISO 9000 and QS 9000 quality standards. However, the interviewees see a clear trend towards demanding certification in ISO/TS 16949 automotive quality standard from the suppliers.

As previously mentioned, the company has approximately 80 suppliers and, in most cases, there is one supplier for each part acquired. However, if the supplier of a certain part presents any supplying constraint, concerning capacity, quality or any other aspect, the company may take advantage of multiple sourcing.

Approximately $80 \%$ of the suppliers are big-sized companies, and there aren't any companies supplying goods exclusively to this engine assembler. The number of suppliers has decreased last years, as a result of mergers and takeovers taking place in Brazilian automotive industry.

Contracts between the assembler and its suppliers are established with one-year validity, but they are renewed in most of the cases. It implies that the company tries to establish, to some degree, long-germ relationships with its suppliers.

In some cases, the engine assembler develops parts together with the supplier (what the literature has called "co-design"). Among those cases, injection systems and oil bombs could be used as examples. However, according to what could be understood from the interviews, in most cases the suppliers dominate the technology (design and process) of its products, working on a set of specifications received from the engine assembler.

The bargaining power taking place inside the supply chain can vary according to a range of elements. Considering the assembler as the center of analysis, the suppliers' power can change 
according to the position each company holds, its size, the relative importance of the products it supplies, as well as time issues.

The assembler assesses suppliers' performance based on the same aspects that it uses in the processes of selecting them: quality, price, technological content and commercial relationship.

Another aspect of the assembler-supplier relationship that is worth mentioning is the fact that the assembler only has contact with its immediate (first-tier) suppliers. Differently form other engine-assembly companies, that get into direct contact to second-tier suppliers and take advantage of their bargaining power to get better purchasing conditions, the company here studied adopts the strategy of only having relationship with few, big-sized, immediate suppliers.

\subsection{Logistics}

The company has about 80 national suppliers, responsible for providing approximately 1500 parts. From these 80 enterprises, about $80 \%$ to $90 \%$ are located in the state of São Paulo, and other $5 \%$ in the state of Rio Grande do Sul.

Besides these national parts, other 300 foreign parts are supplied to the assembler via its headquarters in Europe, which receives the foreign-material scheduling from the Brazilian branch and gets responsible for distributing it to the abroad suppliers.

The studied company adopts VMI - "Vendor Managed Inventory" - practices, having what it calls "Shopping Centers" inside its plants. By means of such Shopping Centers, direct and indirect-material suppliers have installed themselves inside the assembler plant, in an area designed by the studied company, in order to provide the supplies the assembler needs. This way, the assembler is able to reduce its working capital by not burdening its inventories, once that handling, warehousing and transportation are responsibilities of the suppliers, and the products are only billed when they are effectively used.

Currently, there are 8 suppliers installed in "Shopping Centers" inside the plant, making available direct materials like oil, screws, rivets, nuts and bolts, besides indirect materials like tools. Given the characteristics of this system, the assembler has chosen to use Kanban as a manner to schedule supply with the companies installed in the "Shopping Centers".

Besides the suppliers installed inside the plant, the assembler can count on a group composed of approximately five suppliers that have their materials in storage areas near the plant. Despite not being physically inside the engine assembler, they also provide high flexibility, because their inventories are visible to the studied company and the materials only get into plant when they are actually ordered.

Another singularity of the assembler logistical system is the existence of a material reception 
center settled outside of the company (in the state of São Paulo, to be more specific). The operation of this center is outsourced, being the contracted company liable for receiving, storing, consolidating loads, and transporting to the engine assembler.Besides, such center is used by suppliers which returns on sales to the assembler would not justify undertaking a "follow sourcing" practice. However, it's worth noting that "follow sourcing" has been adopted by some company suppliers.

Internally to the engine assembler, the production is based on issuing orders, and Kanban is just applied in the machining portion of the plant.

Inventory management in the plant is aimed at providing flexibility, as well as reducing working capital immobilized in its inventories. Safety stock is about 30 days for foreign materials (between the in-house stock and the headquarters warehouse, responsible for importations). For national materials, it has an average of 5 days, but for most products it's only 1.5 days.

The finished-good stock has coverage of 0.9 days. This way, if the car assembler demands 1400 engines/day, the engine company must keep a diary stock of about 1200 engines.

With this inventory policy, the enterprise aims at achieving a 12.5 days working capital, being necessary to point out that, from all the worldwide plants of this car and engine assembly company, the one studied has the lowest working capital immobilized in inventories.

Basically, all the logistical services are outsourced. The contracted company is responsible for receiving, handling and storing the parts, for the internal logistics, and for the transporting finished products to the car assembler. The engine assembler just supervises the activities performed by the contracted company.

Concluding, it's worth noting the existence of an independent packaging department. After the design of a new part, this department must carry out a study, along with the supplier of that part, to determine the best way of packing the material.

\section{Analysis and Final Remarks}

Although the empirical observation basis could be here considered restricted in order to make recommendations on Supply Chain Management, it's important to emphasize that the case study carried out at the engine assembler included questions regarding clients and suppliers, as a manner to embrace its whole supply chain.

One should also consider that the studied company suppliers are not exclusive and, therefore, they take part in other chains form the automotive engine industry. Thus, the main suppliers serve, in most cases, different assemblers simultaneously and undertake strategies that must be compatible to their clients. 
The case study here presented indicates that Logistics (at least in the way it's understood by the literature that supports this work and the way it's performed by the company) can not be used as a synonym to Supply Chain Management, once that the latter embodies a set of activities, like developing products together with suppliers, managing supply quality, managing technologically strategic items, among others, that goes beyond controlling the flow of products and corresponding information.

Flexibility, the logistical need that was most emphasized by the interviewees, impacts on structure and relationship between the companies in the supply chain. Given such necessity, the strategic choice made by the company was to develop closer relation to a smaller number of biggersized suppliers, and thus passing this quest for flexibility to them. This way, the assembler assigns its first-tier suppliers the responsibility for increasing its flexibility and coordinating such increase along with the lower-tier suppliers, getting around such task as well as the necessity of getting in direct contact with those lower-tier suppliers.

This choice corroborates the proposition of Alves Filho et al. (2000), which states that not all chain links need to be coordinated, being thus necessary to determine which chain parts deserve more attention, according to a series of factors, like the company's capabilities and the level of importance of each subset of parts (and the corresponding suppliers) in the business context.

The strategic choice mentioned above makes it possible to infer that the assembler is able to exert some influence on the chain, in aspects concerning price, quality, product diversity and technological content of parts, as well as of their.

The previous decision of the plant location, in a region of small tradition in Brazilian automotive industry, has generated impact on the structural configuration of the supply chain that also seems to condition some choices on the logistical system configuration, like a "path dependency" on previous strategic choices. Given such choice, the assembler had the necessity of creating a reception center in the ABCD (state of São Paulo) region, of promoting the adoption of follow sourcing practices by some companies, of establishing some inventory policies, among other decisions.

Another issue concerning the supply chain, the amount of parts supplied by international suppliers (300, approximately), has great impact on one of the aspects regarding logistics: inventory management. In the case of the studied assembler, the inventories for national parts had coverage of about 5 days, in contrast to 30 days for imported parts. Besides the longer time inherent to the transportation of the latter, constant problems with customs houses were also mentioned as reasons for increases in inventory levels.

Those inventory levels are significantly different from another engine assembler mentioned by Maia (2006). In this other case, the inventories for national parts had coverage of about 2 days 
and 15 days for imported parts. Although it is not intended, here, to discuss such fact in detail, such difference comes to corroborate the influence that supply chain structure exerts on logistical activities (inventory management), once that the mentioned assembler has its plants located close to the $\mathrm{ABCD}$ region, where most of the auto suppliers are located, and is closer to the importing port.

Given what was presented above, the case studied makes its contribution in the sense of highlighting the strong inter-relationship taking place between aspects that compose Supply Chain Management, here included logistics (location, inventory, and transportation, among others) and the characteristics of structure, relationship and alignment pertaining to Supply Chain Management.

At least in the case studied, given this strong mutual influence among its factors, as well as the dependence on previous strategic choices, decisions made in the Supply Chain Management sphere, and consequently in the logistics one, are assigned even more complexity and strategic relevance.

In this sense, the strategy undertaken by the engine assembler studied seems to be contingent upon environmental conditions in which the company is inserted, as well as upon strategic choices made in the past. Obviously, this strategy for Supply Chain Management may not be the best or the most adequate one in all cases. Distinct assemblers, inserted into different structural, technological and strategic contexts, should adopt a conduct that is most suitable to its context and to the strategic direction they want to implement.

\section{References}

Alves Filho, A.G., Rachid, A.; Donanone, J.C.; Martins, M.F.; Truzzi, O; Bento, P.; \& Vanalle, R.M. Supply chain assembler control: the case of Volkswagen's engine plant of São Carlos-SP-Brazil. In: 8ème Rencontre International du Gerpisa, France, 2000.

Alves Filho, A.G. Rachid, A.; Donanone, J.C.; Martins, M.F.; Truzzi, O; Bento, P.; \& Vanalle, R.M . O consórcio modular e seus impactos na cadeia de suprimentos da fábrica de motores VW-São Carlos. Final Report, Thematic Project, FAPESP Process 97/13071-9, Brazil, 2001.

Alves Filho, A. G..; Cerra, A. L.; Maia, J. M.; Sacomano Neto, M.; \& Bonadio, P.V.G. Pressupostos da Gestão da Cadeia de Suprimentos: evidências de estudos sobre a indústria automobilística. Gestão \& Produção, v. 11, n. 3, p. 275-288, 2004.

Ballou, R.H. Business Logistics Management: Planning, Organizing and Controlling the Supply Chain. Englewood Cliff, NJ: Prentice Hall, 4th Edition, 1999.

Bowersox, D. J.; \& Closs, D. J. Logistical Management: The integrated Supply Chain Process, Ney Work, NY: McGraw-Hill, 1996.

Chopra, S.; \& Meindl, P. Gerenciamento da Cadeia de Suprimentos: Estratégia, Planejamento e Operação. São Paulo, Brazil: Prentice Hall, 2003.

Christopher, M. Logistics and Supply Chain Management: Strategies for Reducing Cost and Improving Service. Englewood Cliff, NJ : Prentice Hall, 2nd Edition, 1998.

Council of Supply Chain Management Professionals Supply Chain/Logistics Management Definitions. Disponível em <http://www.cscmp.org $>$. Dec/2005. 
Croom, S.; Romano, P.; \& Giannakis, M. Supply Chain Management: an analytical framework for critical literature review. European Journal of Purchasing and Supply Management, v. 6, n. 1, p. 67-83, 2000.

Gil, A. C. Métodos e Técnicas de Pesquisa Social. Brazil: Atlas, 5th Edition, 1999.

Lambert, D. M.; Emmelhainz, M. A.; Gardner, J. T. Developing and Implementing Supply Chain Partnerships. The International Journal of Logistics Management. v. 9, n. 2, p. 1-17, 1996.

Lazzarini, S. G. Estudos de caso: aplicações e limites do método. In: Farina, E. Estudos de caso em agribusiness. São Paulo, Brazil: Pioneira, 1997.

Lumus, R. R.; Vokurka, R.J.; \& Alber, K. L. Strategic supply chain planning. Production and Inventory Management Journal, v.39, p. 49-58., 1998.

Maia, J. L. Alinhamento entre a Estratégia de Operações e a Gestão Estratégica da Logística: Estudos de caso no setor automotivo brasileiro. M.Sc. Dissertation, Operations Engineering, DEP/UFSCar, 2006.

Musetti, M. A. A identificação da entidade gestora logística: uma contribuição para seu processo de formação e educação. PhD Thesis (Mechanic Engineering), EESC-USP, 2000.

Pedroso, M.C Um estudo sobre o desenvolvimento de competências em Gestão de Cadeia de Suprimentos. Ph.D. Thesis, Polytechnic School, University of São Paulo, Brazil, 2002.

Pires, S. R. I.; \& Ayres, A. P. S. Strategic Management of Logistics and Supply Chain: a case of Increasing and Fostering the Competitiveness of a TNC subsidiary in Brazil. In: Fleury, A.; Yoshizaki, H.; Guimarães, L. B. M.; \& Ribeiro, J. L. D. (Eds) Building Competencies for International Manufacturing: Perspectives for developing countries, Brazil: FEENG, p. 36-43, 2000.

Posthuma, A.C. Autopeças na encruzilhada: modernização desarticulada e desnacionalização. In: Arbix, G.; \& Zilbovicius, M. (Eds). De JK a FHC: a reinvenção dos carros. São Paulo, Brazil: Scritta, 1997

Salerno, M. S.; Marx, R.; \& Zilbovicius, M. A nova configuração da cadeia de fornecimento na indústria automobilística do Brasil. Revista de Administração da USP, v. 38, n. 3, p. 192-204, 2003.

Slack, N.; Chambers, S.; \& Johnston, R. Administração da Produção. São Paulo, Brazil: Atlas, 2nd Edition, 2002.

Souza, M. F. S. ; Moori, R. G. ; Marcondes, R. C. Sincronismo entre clientes e fornecedores. RAE. Revista de Administração de Empresas, v. 45, p. 36-49, 2005.

Yin, R.K. Case study research: design and methods. Sage publications, Newbury Park, 1989.

\section{Inserir aqui dados completos de TODOS os autores:}

Nome completo: Jonas Lucio Maia

Filiação institucional: UFSCar - Universidade Federal de São Carlos

Departamento: Depto de Engenharia de Produção

Função ou cargo ocupado: Doutorando em Engenharia de Produção

Endereço completo para correspondência (bairro, cidade, estado, país e CEP): Rod. Washington

Luiz, Km 235, CEP 13565-905, São Carlos, SP, BRASIL

Telefones para contato: (16)3351-8236 (r 9223)

e-mail: jonasmaia@dep.ufscar.br

Nome completo: Aline Lamon Cerra 
Filiação institucional: UFSCar - Universidade Federal de São Carlos

Departamento: Depto de Engenharia de Produção

Função ou cargo ocupado: Pós-doutoranda em Engenharia de Produção

Endereço completo para correspondência (bairro, cidade, estado, país e CEP): Rod. Washington Luiz, Km 235, CEP 13565-905, São Carlos, SP, BRASIL

Telefones para contato: (16)3351-8236 (r 9223)

e-mail: alinelc@terra.com.br 